\title{
Effect of milk pasteurization and curd scalding temperature on proteolysis in Malatya, a Halloumi-type cheese
}

\author{
Ali A. Hayaloglu ${ }^{1 *}$, Kevin C. Deegan ${ }^{2,3}$, Paul L.H. McSweeney ${ }^{2}$ \\ ${ }^{1}$ Department of Food Engineering, Inonu University, 44280 Malatya, Turkey \\ ${ }^{2}$ Department of Food and Nutritional Sciences, University College, Cork, Ireland \\ ${ }^{3}$ Present address: Department of Food and Environmental Science, University of Helsinki, Finland
}

\begin{abstract}
Received 4 August 2009 - Revised 15 October 2009 - Accepted 10 November 2009
Published online 19 January 2010
\end{abstract}

\begin{abstract}
The effect of pasteurization of cheese milk and cooking temperature of the curd on proteolysis of Malatya cheese was examined during ripening. The cheeses that were characterized by the scalding of curd in hot whey were manufactured from raw or pasteurized milk and the curds were scalded in hot whey at $60,70,80$ or $90{ }^{\circ} \mathrm{C}$. Differences in the levels of $\mathrm{pH} 4$.6-soluble nitrogen between cheeses were significant $(P<0.05)$ after 30 days of ripening. Urea-polyacrylamide gel electrophoresis of the $\mathrm{pH}$ 4.6-insoluble fractions showed that both $\alpha_{\mathrm{s} 1}$ - and $\beta$-caseins were not extensively degraded, especially after 30 days of ripening, but $\beta$-casein was less degraded than $\alpha_{\mathrm{s} 1}$-casein. Analysis of peptide profiles of the $\mathrm{pH}$ 4.6-soluble fractions by RP-HPLC showed significant differences in the concentrations of some peptides between the cheeses. Principal component analysis distinguished the cheeses made from raw or pasteurized milk based on their peptide profiles. The results suggest that the pasteurization of cheese milk had a greater effect on peptide profiles of cheese than scalding temperature of the curd.
\end{abstract}

Malatya cheese / proteolysis / scalding / raw milk / pasteurization

摘要 - 原料奶的巴氏杀菌和凝块热涊温度对 Malatya 干酪蛋白水解的影响。Malatya 干酪属 于 Halloumi 干酪的一种。本文研究了原料奶的巴氏杀菌和凝块的热粱温度对 Malatya 干酪 蛋白水解的影响 研究了由生乳和巴氏杀菌乳形成的凝块分别在 $60 、 70 、 80$ 和 $90^{\circ} \mathrm{C}$ 热乳 清中热梁后制成干酪的性质。成熟 $30 \mathrm{~d}$ 后, 各干酪在 $\mathrm{pH} 4.6$ 可溶性氮的水平上差异显著 $(P<0.05)$ 。 $\mathrm{pH} 4.6$ 不溶性蛋白部分的尿素-聚丙烯酰胺凝胶电泳的试验结果证明了成熟 $30 \mathrm{~d}$ 后, $\alpha_{\mathrm{s} 1}$-酪蛋白和 $\beta$-酪蛋白的降解都不明显, 相比之下, $\beta$-酪蛋白的降解程度低于 $\alpha_{\mathrm{s} 1}$-酪 蛋白。反相-高效液相色谱分析结果证明了各干酪样品的 $\mathrm{pH} 4.6$ 可溶性部分中某些肽的浓 度显著不同。主成分分析 (PCA) 说明了生乳和巴氏杀菌乳与干酪中肽特性之间有显著的相 关性。研究显示原料乳的巴氏杀菌对干酪中肽特性的影响程度大于凝块的热汤温度。

\section{Malatya 干酪 / 蛋白水解 / 热淡 / 生乳 / 巴氏杀菌}

Résumé - Effet de la pasteurisation du lait et de la température de chauffage du caillé sur la protéolyse du Malatya, un fromage de type Halloumi. Les effets de la pasteurisation du lait de fabrication et de la température de cuisson du caillé sur la protéolyse du fromage Malatya ont été examinés pendant l'affinage. Les fromages qui sont caractérisés par la cuisson du caillé dans du

*Corresponding author (通讯作者): ahayaloglu@inonu.edu.tr 
lactosérum chaud ont été fabriqués à partir de lait cru ou pasteurisé et les caillés ont été traités dans du lactosérum chauffé à $60,70,80$ ou $90^{\circ} \mathrm{C}$. Les différences de teneur en azote soluble à pH 4,6 entre fromages étaient significatives $(P<0,05)$ après 30 jours d'affinage. L'électrophorèse sur gel de polyacrylamide en milieu urée des fractions insolubles à $\mathrm{pH} 4,6$ a montré que les deux caséines $\beta$ et $\alpha_{\mathrm{s} 1}$ n'étaient pas beaucoup dégradées, en particulier après 30 jours d'affinage, mais la caséine $\beta$ était moins dégradée que la caséine $\alpha_{\mathrm{s} 1}$. L'analyse du profil peptidique par chromatographie RP-HPLC des fractions solubles à $\mathrm{pH}$ 4,6 a montré des différences significatives dans les concentrations de quelques peptides entre fromages. L'analyse en composante principale différenciait les fromages au lait cru de ceux au lait pasteurisé à partir de leur profil peptidique. Les résultats suggèrent que la pasteurisation du lait de fabrication a un effet plus grand sur les profils peptidiques des fromages que la température de chauffage du caillé.

\section{fromage Malatya / protéolyse / chauffage / lait cru / pasteurisation}

\section{INTRODUCTION}

Cheese ripening is a complex and dynamic biochemical process that includes protein breakdown, fat hydrolysis, and lactose, lactate and citrate metabolism. Proteolysis is catalyzed by proteolytic enzymes from the coagulant, milk and bacteria including starter, nonstarter or secondary starter organisms $[8,21]$. The coagulant is mainly responsible for hydrolyzing the caseins to large and intermediate-sized peptides $[16,18]$.

Cheese made from raw milk generally ripens faster and develops a stronger, more intense flavor than the cheese made from pasteurized milk [19]. Lau et al. [17] reported that a cheese made from pasteurized milk took twice as long to develop the same flavor intensity as one made from raw milk. Lower levels of soluble nitrogen and free amino acids were found in cheese made from pasteurized milk [7, 20]. The native and starter microorganisms and indigenous milk enzymes play a major role in the formation of small peptides and free amino acids, and are main contributors to the formation of the characteristic aroma components in cheese [29]. Heat treatment of milk prior to cheesemaking affects the microbial flora, proteolysis, free amino acids, free fatty acids, volatile fractions and sensory characteristics of the cheese [8]. Pasteurization can ensure the hygienic and standard quality of cheese, promote safety and achieve better production control [4].
Malatya cheese is traditionally made from raw sheep's or cows' milk, or mixtures thereof, and no starter is added, and thus acidification is brought about by the natural microflora of the milk. The traditional cheesemaking procedure is still used in farms and villages. However, recently, some cheesemakers have used pasteurized milk and an added starter culture to standardize production. Scalding at $80-90{ }^{\circ} \mathrm{C}$ is the usual practice in Malatya cheesemaking, which gives the curd an elastic and compact texture after pressing. The scalding procedure is a crucial step in Malatya cheesemaking, and the process substantially affects the physical, biochemical and sensory properties of the cheese [10]. The heating process in Malatya cheese is different from that in pasta-filatatype cheeses. The stretching temperature in the manufacture of pasta-filata-type cheeses is not higher than $75^{\circ} \mathrm{C}$ for a short time during plasticization. In addition, cooking is applied to cheese curd before the cheese has been formed, and the curd cannot be stretched in hot water (containing salt ca. 5-7\%) unless the $\mathrm{pH}$ reaches 5.1-5.3. Therefore, acidification and stretching in salted hot water are essential steps for the manufacture of pasta-filata-type cheeses. However, these are not necessary in the manufacture of Malatya cheese. On the other hand, the cooking operation in Malatya cheese is slightly different from Halloumi cheese. In the traditional or home manufacture of Malatya cheese, the heating 
temperature ranges over a wide interval $\left(60{ }^{\circ} \mathrm{C}\right.$ to the boiling temperature of whey) and the duration (it varies among artisanal producers) varies widely. However, cooking at temperatures from $80-90{ }^{\circ} \mathrm{C}$ for $3-5 \mathrm{~min}$ is usual in industrial production, but it varies between factories. There are some differences between traditional and industrial cheeses in terms of scalding temperatures and, to the authors' knowledge, no information is available on the effect of scalding temperatures on proteolysis and any other ripening indices of the cheese. We aimed to investigate the effect of pasteurization of cheese milk and cooking temperature of the curd on the proteolysis of Malatya cheese during ripening.

\section{MATERIALS AND METHODS}

\subsection{Cheese making}

Malatya cheese was made in duplicate, using both raw and pasteurized cows' milk in a local dairy plant (Karlidag Dairy Products, Malatya, Turkey). Raw milk cheeses (R cheeses) were made from $100 \mathrm{~L}$ of cow's milk. An equal quantity of milk was pasteurized $\left(72{ }^{\circ} \mathrm{C}\right.$ for $\left.30 \mathrm{~s}\right)$ and used for the manufacture of pasteurized milk cheeses ( $\mathrm{P}$ cheeses). After pasteurization, the milk was cooled to $32{ }^{\circ} \mathrm{C}$, and the commercial culture consisting of Lactococcus lactis ssp. lactis and Streptococcus thermophilus (Sacco, S.R.L., Cadorago, Italy) was added to $\mathrm{P}$ cheeses at the manufacturer's recommended dose and held for 30-45 min. Milk for both $\mathrm{R}$ and $\mathrm{P}$ cheeses was coagulated using commercial calf rennet $(>85 \%$ chymosin, REN-NA ${ }^{\circledR}$, Mayasan, Istanbul, Turkey) at a level of $15 \mathrm{~g} \cdot 100 \mathrm{~L}^{-1}$. The milk was allowed to coagulate at $32{ }^{\circ} \mathrm{C}$ for $45 \mathrm{~min}$. Following coagulation, the curd was cut and stirred for about $30 \mathrm{~min}$, transferred into cloth bags and then left for $30 \mathrm{~min}$ to facilitate whey drainage without pressing. The bags, that contained $\sim 250 \mathrm{~g}$ of curd were tied up and molded into a ball, and then they were pressed between two wooden blocks for $2 \mathrm{~h}$. The curds were scalded at $60,70,80$ or $90{ }^{\circ} \mathrm{C}$ for $3 \mathrm{~min}$ by dipping them into their own wheys. Afterwards, the curd blocks were re-pressed between the same wooden blocks for $3 \mathrm{~min}$ and then immediately cooled to room temperature using potable water. Finally, the cooled blocks were immersed in brine $(10 \% \mathrm{NaCl})$ for about $16 \mathrm{~h}$. The salted cheese blocks were kept in the same brine $(10 \% \mathrm{NaCl})$ and ripened for 90 days at $6-8{ }^{\circ} \mathrm{C}$.

\subsection{Chemical composition}

Cheeses were analyzed, in duplicate, for moisture content by the oven-drying method at $102{ }^{\circ} \mathrm{C}$ [11], for salt content by titration with $\mathrm{AgNO}_{3}$ [6], for fat content by the Van Gulik method [3] and for total nitrogen (TN) content by the Kjeldahl method [12]. For $\mathrm{pH}$ measurement, grated cheese $(10 \mathrm{~g})$ was macerated with $10 \mathrm{~mL}$ of distilled water, and the $\mathrm{pH}$ of the resultant slurry was measured using a digital $\mathrm{pH}$ meter ( $\mathrm{pH}$ 211, Hanna Instruments, Vila do Conde, Portugal). Titratable acidity was determined as $\mathrm{g}$ lactic acid/100 $\mathrm{g}$ cheese using the method of AOAC [2].

\subsection{Proteolysis}

The $\mathrm{pH}$ 4.6-soluble ( $\mathrm{pH}$ 4.6-SN) fraction as percentage of $\mathrm{TN}$ of the cheese was prepared according to the method of Kuchroo and Fox [15], and determined by the Kjeldahl method [12]. Urea-PAGE (4\% C (cross-linking agent as a percentage of total monomers), $12.5 \% \mathrm{~T}$ (total monomer), $\mathrm{pH} 8.9$ ) of the $\mathrm{pH}$ 4.6-insoluble fraction of the cheeses was performed using a Protean II XI vertical slab-gel unit (Bio-Rad Laboratories Ltd., Watford, UK) according to the method of Andrews [1], as modified by Shalabi and Fox [27]. Freezedried samples $(10 \mathrm{mg})$ of the $\mathrm{pH} 4$ 46-insoluble fraction from each sample were dissolved in $1 \mathrm{~mL}$ of electrophoresis sample buffer and 
vortexed, and/or sonicated, if necessary, for $1 \mathrm{~min}$ and stored at $-20{ }^{\circ} \mathrm{C}$ until analyzed. Prior to electrophoresis, frozen samples were heated at $50{ }^{\circ} \mathrm{C}$ for a few minutes and then cooled to room temperature. An aliquot $(7 \mu \mathrm{L})$ of each sample was loaded onto the gel. Electrophoresis was performed through the stacking and separating gels at 280 and $300 \mathrm{~V}$, respectively. The gels were stained directly by the method of Blakesley and Boezi [5] with Coomassie Brilliant Blue G-250 and destained using distilled water. After destaining, gel slabs were digitized by a scanner (HP ScanJet software, ScanJet 6300C, Hewlett Packard, USA).

Peptide profiles of the $\mathrm{pH}$ 4.6-soluble fraction of samples of Malatya cheese were determined by RP-HPLC using a Varian HPLC system (Varian Associates Inc., Walnut Creek, CA, USA) as described by Hayaloglu et al. [9]. The system was comprised of an autosampler (Model 410), a ProStar solvent delivery system with three pumps (Model 230), and a ProStar programmable multiwavelength spectrophotometer (Model 310) interfaced with a PC, in which a Varian Star Workstation 5 software package was installed for system control and data acquisition. Nucleosil RP-8 $(250 \times 4 \mathrm{~mm}, 5 \mu \mathrm{m}$ particle size, $300 \AA$ pore size) analytical and guard columns $(4.6 \times 10 \mathrm{~mm})$ (Capital HPLC Ltd., Broxburn, West Lothian, UK) were used. The solvents were: (A) $0.1 \%(\mathrm{v} / \mathrm{v})$ trifluoroacetic acid (TFA, sequencing grade; Sigma, St. Louis, MO, USA) in deionized HPLCgrade water (Milli-Q system, Waters Corp., Molshem, France) and (B) $0.1 \%(\mathrm{v} / \mathrm{v})$ TFA in acetonitrile (HPLC grade, Lab-Scan Ltd., Dublin, Ireland) at a flow rate of $0.75 \mathrm{~mL} \cdot \mathrm{min}^{-1}$. Samples of freeze-dried $\mathrm{pH}$ 4.6-soluble fraction were dissolved in solvent $A\left(10 \mathrm{mg} \cdot \mathrm{mL}^{-1}\right)$ and filtered through a $0.45 \mu \mathrm{m}$ cellulose acetate filter (Sartorius GmbH, Göttingen, Germany); an aliquot $(40 \mu \mathrm{L})$ of filtrate was injected onto the column. The samples were eluted initially with $100 \%$ A for $5 \mathrm{~min}$, then with a gradient from $0 \%$ to $50 \% \mathrm{~B}(\mathrm{v} / \mathrm{v})$ over $55 \mathrm{~min}$, maintained at $50 \% \mathrm{~B}(\mathrm{v} / \mathrm{v})$ for $6 \mathrm{~min}$, followed by a linear gradient from $50 \%$ to $60 \% \mathrm{~B}(\mathrm{v} / \mathrm{v})$ over $4 \mathrm{~min}$, and finally with $60 \% \mathrm{~B}(\mathrm{v} / \mathrm{v})$ for $3 \mathrm{~min}$. The column was washed with $95 \% \mathrm{~B}(\mathrm{v} / \mathrm{v})$ for $5 \mathrm{~min}$, followed by equilibration with $100 \% \mathrm{~A}$ for $5 \mathrm{~min}$ before the next injection. Elution was monitored at $214 \mathrm{~nm}$.

\subsection{Multivariate analysis}

Data from the RP-HPLC chromatograms of the $\mathrm{pH}$ 4.6-soluble fractions of the cheeses were analyzed using multivariate statistical techniques to simplify interpretation of the data from RP-HPLC. Principal component analysis (PCA) was performed using a covariance matrix and varimax rotation between the cheeses. The peak heights for all RP-HPLC data were used as variables and PCA was carried out using The Unscrambler v9.6 free-trial version (CAMO, Software AS, Oslo, Norway).

\section{RESULTS AND DISCUSSION}

\subsection{Chemical composition and $\mathrm{pH}$}

The chemical composition of Malatya cheese at 1 day of ripening is shown in Table I. No significant differences $(P>0.05)$ were found between cheeses in terms of total solids, salt and fat-in-dry matter. However, a higher level of titratable acidity and lower $\mathrm{pH}$ values were found in the cheeses made from pasteurized milk with an added starter culture than in raw milk cheeses $(P<0.05)$. The addition of starter culture to the pasteurized milk resulted in a significantly lower $\mathrm{pH}$ in pasteurized milk cheeses $(\mathrm{P})$ in comparison to raw milk cheeses (R) early in ripening. The lower $\mathrm{pH}$ of the $\mathrm{P}$ cheeses than that of the $\mathrm{R}$ cheeses early in ripening suggested that the starter bacteria were resisted to the scalding temperature. Differences between 
Table I. Chemical composition of Malatya cheese made from raw $(\mathrm{R})$ and pasteurized $(\mathrm{P})$ milk after 1 day of ripening. Codes $60,70,80$ or 90 refer to scalding temperature of the curd $\left({ }^{\circ} \mathrm{C}\right)$.

\begin{tabular}{lccccc}
\hline Cheeses & \multicolumn{5}{c}{ Variables } \\
\cline { 2 - 6 } & Titratable acidity & Total solid (\%) & Salt (\%) & FDM $^{2}(\%)$ & Total protein (\%) \\
\hline R60 & $0.21 \pm 0.08^{\mathrm{ab}}$ & $39.85 \pm 0.55^{\mathrm{a}}$ & $2.70 \pm 0.0^{\mathrm{a}}$ & $42.03 \pm 0.05^{\mathrm{a}}$ & $14.03 \pm 0.32^{\mathrm{ab}}$ \\
R70 & $0.14 \pm 0.0^{\mathrm{a}}$ & $40.20 \pm 0.30^{\mathrm{a}}$ & $2.81 \pm 0.0^{\mathrm{a}}$ & $41.64 \pm 2.79^{\mathrm{a}}$ & $15.04 \pm 014^{\mathrm{bcd}}$ \\
R80 & $0.22 \pm 0.09^{\mathrm{ab}}$ & $38.79 \pm 0.70^{\mathrm{a}}$ & $2.70 \pm 0.0^{\mathrm{a}}$ & $45.74 \pm 1.10^{\mathrm{a}}$ & $16.20 \pm 0.28^{\mathrm{d}}$ \\
R90 & $0.23 \pm 0.07^{\mathrm{ab}}$ & $38.90 \pm 1.55^{\mathrm{a}}$ & $2.70 \pm 0.0^{\mathrm{a}}$ & $49.48 \pm 0.04^{\mathrm{a}}$ & $15.68 \pm 0.05^{\mathrm{d}}$ \\
P60 & $0.37 \pm 0.03^{\mathrm{b}}$ & $39.22 \pm 0.17^{\mathrm{a}}$ & $1.93 \pm 0.0^{\mathrm{a}}$ & $44.60 \pm 2.35^{\mathrm{a}}$ & $13.74 \pm 0.50^{\mathrm{a}}$ \\
P70 & $0.39 \pm 0.01^{\mathrm{b}}$ & $39.20 \pm 0.75^{\mathrm{a}}$ & $1.76 \pm 0.0^{\mathrm{a}}$ & $44.68 \pm 2.13^{\mathrm{a}}$ & $14.94 \pm 0.69^{\text {bcd }}$ \\
P80 & $0.30 \pm 0.02^{\mathrm{ab}}$ & $40.75 \pm 2.55^{\mathrm{a}}$ & $2.70 \pm 0.0^{\mathrm{a}}$ & $41.72 \pm 0.15^{\mathrm{a}}$ & $14.25 \pm 0.0^{\mathrm{abc}}$ \\
P90 & $0.29 \pm 0.04^{\mathrm{ab}}$ & $40.22 \pm 0.52^{\mathrm{a}}$ & $2.46 \pm 0.0^{\mathrm{a}}$ & $42.33 \pm 5.52^{\mathrm{a}}$ & $15.36 \pm 0.01^{\text {cd }}$ \\
\hline
\end{tabular}

Mean \pm SD of duplicate determination in two cheese making trials. Mean values in the same column followed by different letters differ $(P<0.05)$.

${ }^{1}$ Titratable acidity expressed as g lactic acid/100 g cheese.

${ }^{2}$ FDM: fat-in-dry matter.

the $\mathrm{pH}$ values of $\mathrm{P}$ and $\mathrm{R}$ cheeses decreased as ripening period proceeded (Fig. 1). The gross composition of the cheese samples at the beginning of the ripening period is in the normal range for a brine-ripened cheese. These results are in agreement with those of Ozer et al. [24] for Urfa cheese and Kahyaoglu and Kaya [13] for Gaziantep cheese that is scalded and ripened in brine-like Malatya cheese.

\section{2. pH 4.6-soluble nitrogen}

Levels of $\mathrm{pH}$ 4.6-soluble nitrogen (SN), expressed as percentage of TN, in Malatya cheese, are shown in Figure 2. Use of raw milk in the manufacture of Malatya cheese led to increased levels of $\mathrm{pH}$ 4.6-SN. The levels of $\mathrm{pH} 4.6-\mathrm{SN}$ were similar in all cheeses at 1 day of ripening; however, the values for $\mathrm{pH}$ 4.6-SN were higher in raw milk cheeses than pasteurized milk cheeses as the ripening proceeded. Differences in the levels of $\mathrm{pH} 4.6-\mathrm{SN}$ between raw and pasteurized milk cheeses were significant $(P<0.05)$ after 30 days of ripening and these differences became greater as the ripening advanced. This may be attributed to the proteolytic activity of non-starter lactic acid bacteria that dominate toward the end of ripening $[18,23]$. The expected influence of starter used in the manufacture of $\mathrm{P}$ cheeses on the $\mathrm{pH} 4.6-\mathrm{SN}$ was observed in the inhibitory effect of scalding. However, scalding of curds at different temperatures had no significant effect on the level of $\mathrm{pH}$ 4.6-SN in the cheeses during ripening $(P>0.05)$. The $\mathrm{pH} 4.6-\mathrm{SN}$ was used as a ripening index in cheese and its levels increased during ripening due to the breakdown of casein into peptides of varying molecular weights and free amino acids by the action of the chymosin, plasmin and enzymes of starter or non-starter bacteria [25]. The lower $\mathrm{pH}$ of cheese favors retention of the rennet in the curd and its proteolytic activity was probably higher than that of plasmin. However, scalding temperatures were greater than $60{ }^{\circ} \mathrm{C}$. Proteolytic activity of chymosin or enzymes from microorganisms was reduced under these conditions. Similar results were obtained by the gel electrophoretic analysis of the $\mathrm{pH} 4.6$-insoluble fractions of the cheeses (Fig. 3). Therefore, heat treatment of milk in the manufacture of cheese had a greater effect on the levels of $\mathrm{pH}$ 4.6-SN than the scalding of curd, in particular, at later stages of maturation. 


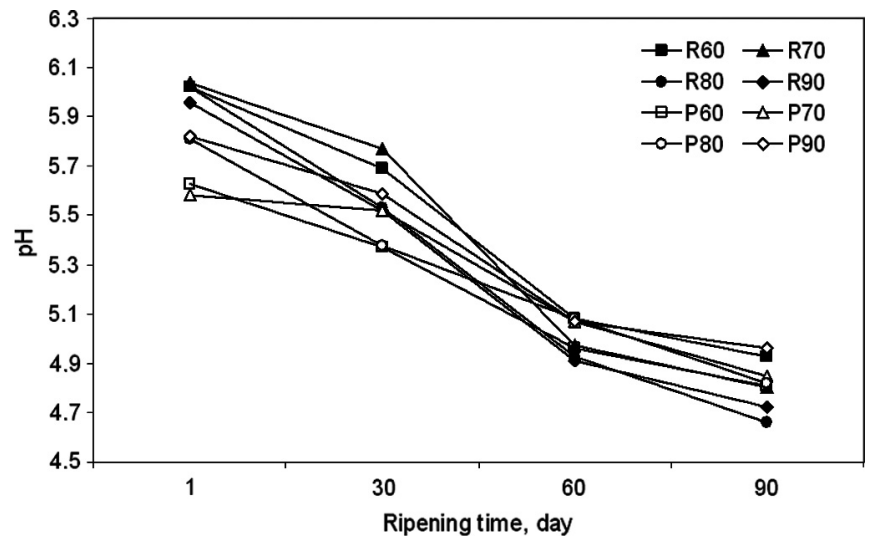

Figure 1. Effect of different scalding temperatures $\left(60,70,80\right.$ or $\left.90{ }^{\circ} \mathrm{C}\right)$ on the $\mathrm{pH}$ profile of Malatya cheese made from raw (R) or pasteurized milk (P). Codes $60,70,80$ or 90 refer to scalding temperature of the curd $\left({ }^{\circ} \mathrm{C}\right)$.

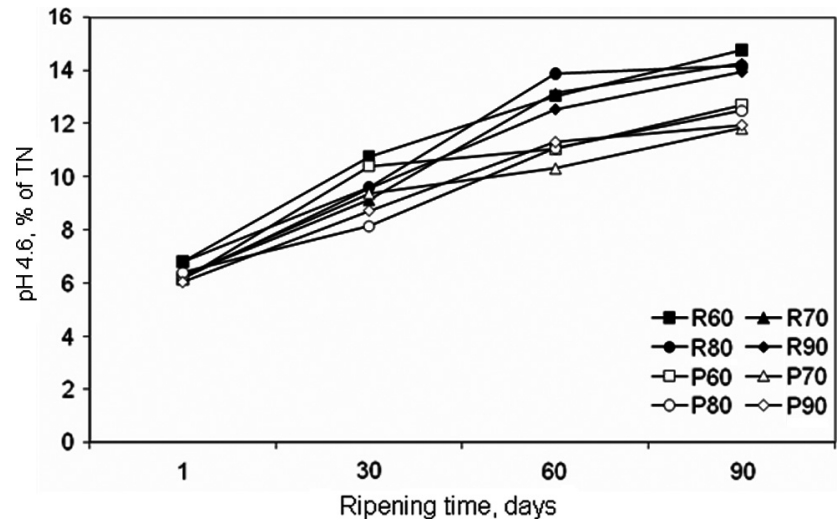

Figure 2. Effect of different scalding temperatures $\left(60,70,80\right.$ or $\left.90{ }^{\circ} \mathrm{C}\right)$ on $\mathrm{pH} 4.6$-soluble $\mathrm{N}$ of Malatya cheese made from raw (R) or pasteurized milk (P). Codes $60,70,80$ or 90 refer to scalding temperature of the curd $\left({ }^{\circ} \mathrm{C}\right)$.

\subsection{Urea-PAGE}

Urea-PAGE electrophoretograms of the $\mathrm{pH}$ 4.6-insoluble fractions of cheeses at $1,30,60$ or 90 days of ripening are shown in Figure 3. Early in ripening, no differences were seen between electrophoretogram of the cheeses made using raw or pasteurized milk. Increased degradation of $\alpha_{\mathrm{s} 1^{-}}$or $\beta$-casein was observed after 30 days ripening. However, considerable differences were observed between raw milk and pasteurized milk cheeses. $\beta$-Casein underwent slight proteolysis during 90 days ripening in all samples, and the intensities of the $\beta$-casein bands were slightly different from those of the young cheeses. Most of the $\beta$-casein remained intact at the end of the ripening 


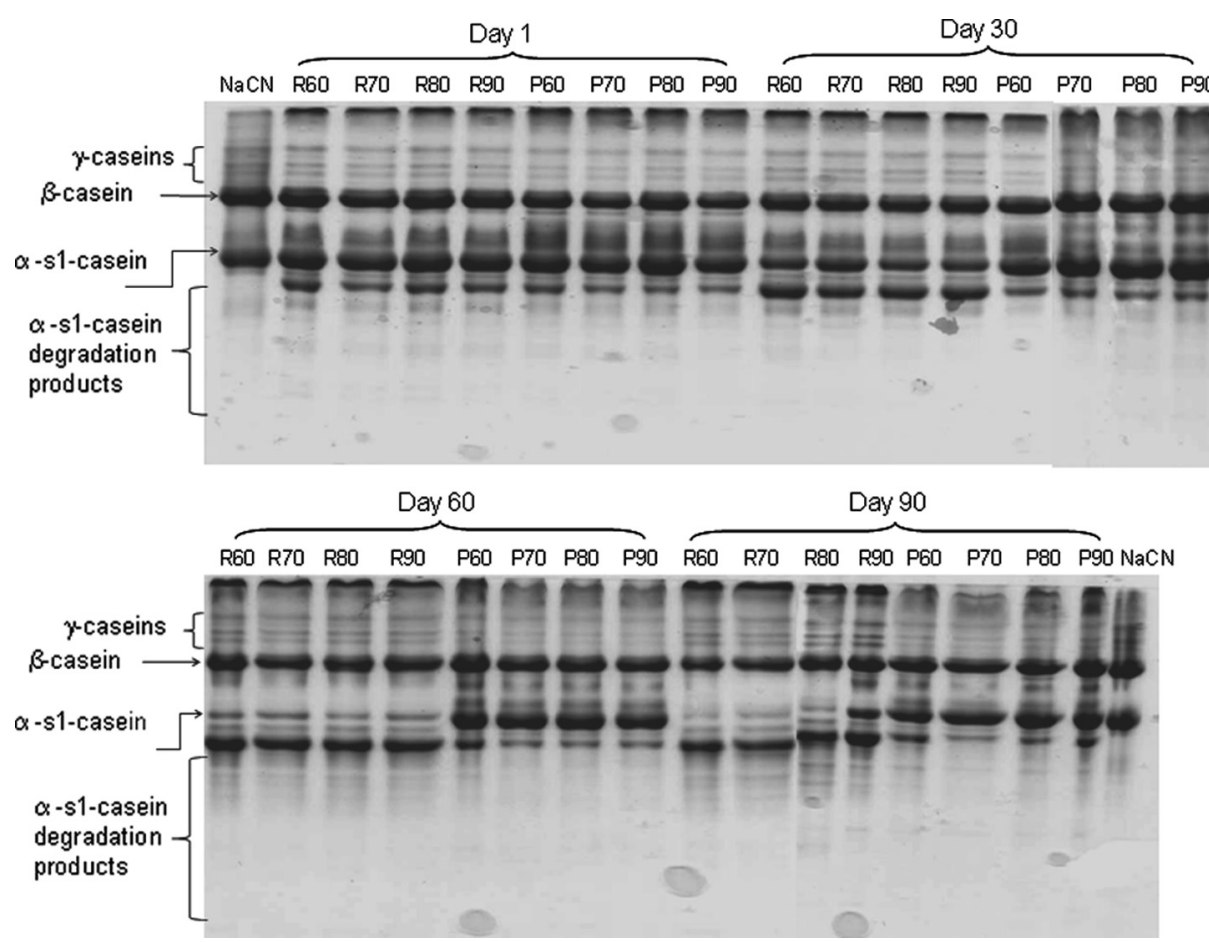

Figure 3. Effect of different scalding temperatures $\left(60,70,80\right.$ or $\left.90{ }^{\circ} \mathrm{C}\right)$ on urea-polyacrylamide gel electrophoretograms of the $\mathrm{pH}$ 4.6-insoluble fractions of Malatya cheese made from raw (R) or pasteurized milk (P). Codes $60,70,80$ or 90 refer to scalding temperature of the curd $\left({ }^{\circ} \mathrm{C}\right)$.

period, indicating that $\beta$-casein was resistant to proteolysis [8]. The intensity of the $\gamma$-casein band slightly increased during ripening. Extensive plasmin activity is not expected in this type of cheese due to its acidity and salt content, both of which are unfavorable for plasmin action $[14,22]$. Extensive hydrolysis of $\alpha_{\mathrm{s} 1}$-casein was observed in the samples at all ripening times. Degradation was more extensive in raw milk cheeses in comparison with the pasteurized milk cheeses, reflecting higher proteolytic activities of raw milk flora against some fragments of $\alpha_{\mathrm{s} 1}$-casein. Differences in $\alpha_{\mathrm{s} 1}$-casein degradation between the two groups of cheese were apparent after 60 or 90 days ripening. Increasing of scalding temperature had no significant effect on both $\alpha_{\mathrm{s} 1}$ - and $\beta$-casein degradation, probably due to the high scalding temperatures used (all $>60^{\circ} \mathrm{C}$ ). Primary proteolysis of casein is mainly achieved by the activity of residual chymo$\sin$ (on $\alpha_{s 1}$-casein). The residual chymosin in the cheese matrix may be largely inactivated even by the lowest scalding temperature used and primary proteolysis in the cheese samples was of the same extent for each sampling time. Sheehan et al. [28] observed that cooking temperatures (47, 50 or $53{ }^{\circ} \mathrm{C}$ ) had a significant inhibitory effect on $\alpha_{\mathrm{s} 1}$-casein degradation or accumulation of mean levels of $\alpha_{\mathrm{s} 1}$-casein (f24-199) during ripening. Differences between Sheehan et al. [28] and the results of this study may be due to the much lower 
(a)

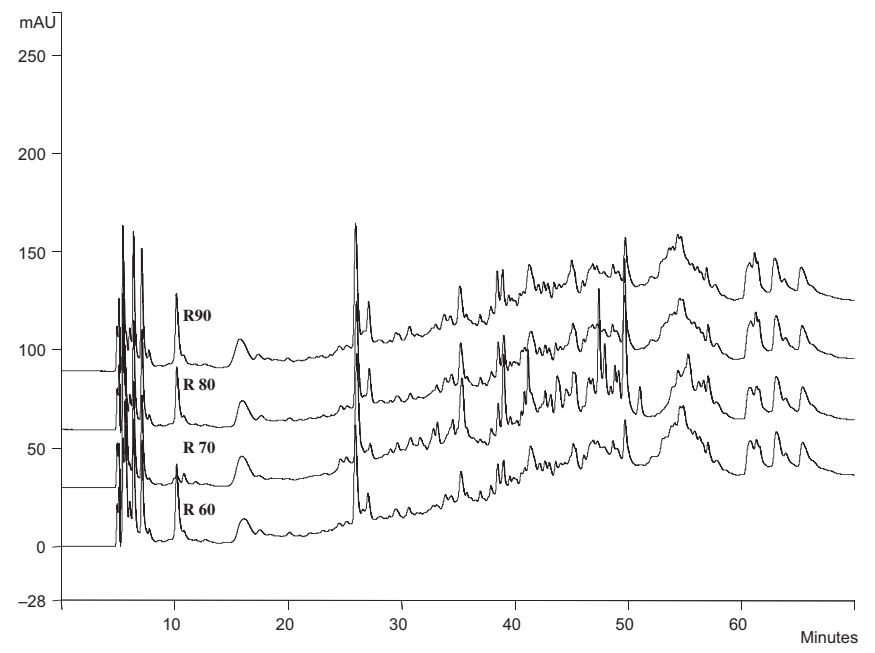

(b)

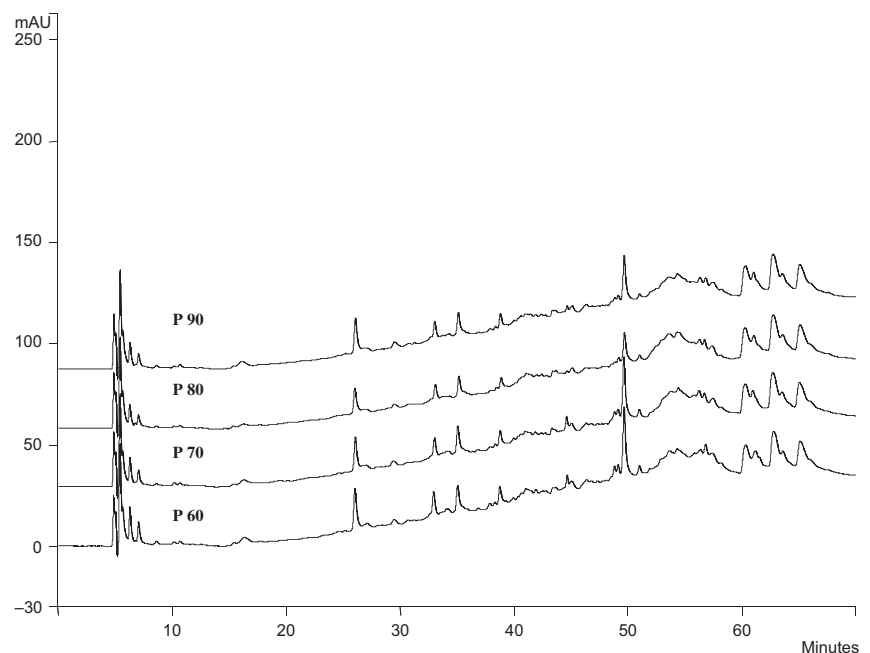

Figure 4. Effect of different scalding temperatures $\left(60,70,80\right.$ or $\left.90{ }^{\circ} \mathrm{C}\right)$ on RP-HPLC peptide profiles of the $\mathrm{pH} 4.6$-soluble fractions of Malatya cheese made from raw (R) (a) and pasteurized (P) milk (b) at 60 days of ripening. Codes $60,70,80$ or 90 refer to scalding temperature of the curd $\left({ }^{\circ} \mathrm{C}\right)$.

cooking temperature used by those authors compared with that used in this study.

\subsection{RP-HPLC}

Reverse-phase HPLC peptide profiles of the $\mathrm{pH}$ 4.6-soluble extracts were performed on the cheeses during ripening and chromatograms of the 60 days old cheeses are shown in Figure 4. No major differences were seen between the peptide profiles of the cheeses scalded at different temperatures; however, both qualitative and quantitative differences were observed between 


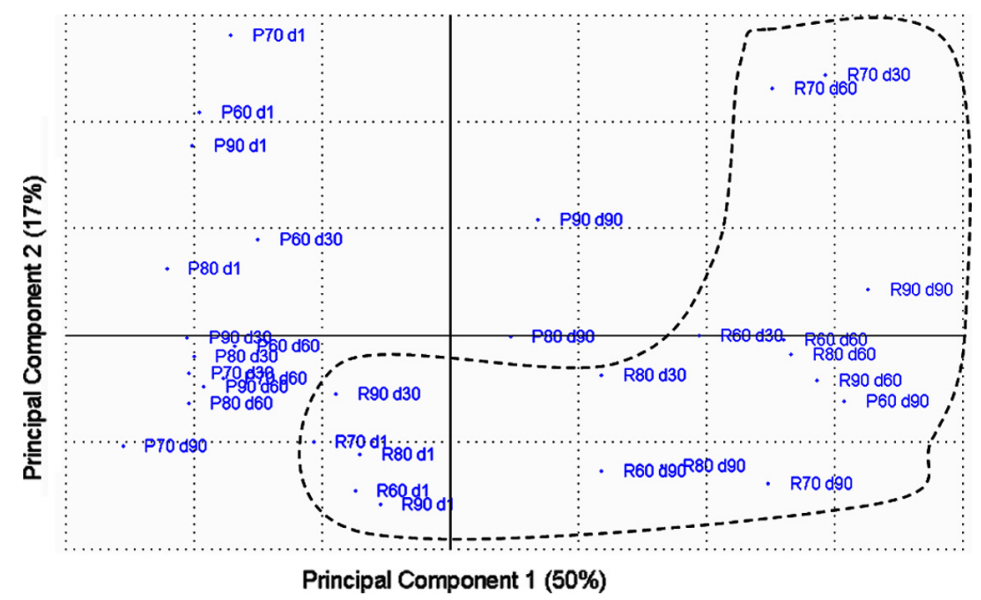

Figure 5. Score plot obtained by PCA of chromatographic data of $\mathrm{pH} 4$ 4.6-soluble fractions of Malatya cheese made from raw $(\mathrm{R})$ or pasteurized $(\mathrm{P})$ milk at 1, 30, 60 or 90 days of ripening. The heights for all RP-HPLC peaks were used as variables in the PCA. PC1 and PC2 accounted for 50\% and $17 \%$ of the variation, respectively. Codes $60,70,80$ or 90 refer to scalding temperature of the curd $\left({ }^{\circ} \mathrm{C}\right)$.

the chromatograms of the cheeses that were made from raw or pasteurized milk. These results of peptide profiles between raw or pasteurized milk cheeses are in agreement with those of Shakeel-Ur-Rehman et al. [26]. In the present study, R cheeses showed higher levels of peptides eluting with early retention times (11 and $16 \mathrm{~min}$ ) than $\mathrm{P}$ cheeses. These peaks were probably due to amino acids or low-molecular weight peptides that were produced by the action of enzymes released by the microflora in raw milk [22]. Raw milk cheeses contained considerably higher concentrations of peptides eluting in hydrophilic or hydrophobic regions than pasteurized milk cheeses. This reflects the extracellular peptidolytic activity of non-starter lactic acid bacteria that contribute to secondary proteolysis of cheese. Differences between the chromatographic profiles obtained from cheese extracts were studied by PCA and the score plot obtained from analysis of peak height data of the RP-HPLC chromatogram is shown in Figure 5. PCA of the peptide profiles of 1, 30,60 or 90 days old cheeses showed that
PC1 and PC2 accounted for 50\% and 17\% of the variation, respectively (Fig. 5). A clear separation was observed between the raw and pasteurized milk cheeses by PCA as indicated on the score plot. The samples were distributed into two main groups: raw milk cheeses located on the right side on PC1 and pasteurized milk cheeses located on the left side of PC1. The cheeses made with raw milk contained higher levels of peptides than did the cheeses made from pasteurized milk. PC1 separated the cheeses on the basis of use of raw or pasteurized milk in cheese manufacture; however, no regular distribution was observed by PC2 based on scalding temperature of the curd. The plots showed that the pasteurization of milk had a greater effect on the peptide profiles of the cheese than scalding temperature of the curd.

\section{CONCLUSIONS}

Indices of proteolysis related to levels of $\mathrm{pH}$ 4.6-soluble or insoluble nitrogenous components were determined. Analysis of 
$\mathrm{pH}$ 4.6-soluble fractions of the cheeses indicated that using raw milk in the manufacture of Malatya cheese increased the level of $\mathrm{pH}$ 4.6-soluble N. Degradation of $\alpha_{\mathrm{s} 1}$-casein observed by urea-PAGE was more extensive in raw milk cheeses in comparison to pasteurized milk cheeses. Pasteurization of milk prior to cheese manufacture had a significant effect on the breakdown of caseins and formation of peptides detectable by RP-HPLC. Throughout the ripening period, it can be concluded that the pasteurization of the milk had a decrease and/or delay effect on the ripening of the cheese. Scalding the curd in hot whey at different temperatures had a slight effect on the proteolysis in Malatya cheese and pasteurization of cheese milk had a greater effect on cheese proteolysis than the scalding temperature of the curd.

\section{REFERENCES}

[1] Andrews A.T., Proteinases in normal bovine milk and their action on caseins, J. Dairy Res. 50 (1983) 45-55.

[2] AOAC, Official Methods of Analysis, 16th edn., AOAC no. 920.124, Association of Official Analytical Chemists, Arlington, USA, 1995.

[3] Ardo Y., Polychroniadou A., Laboratory Manual for Chemical Analysis of Cheese, COST 95, European Communities, Brussels, Belgium, 1999.

[4] Atasoy A.F., Yetismeyen A., Turkoglu H., Ozer B., Effects of heat treatment and starter culture on the properties of traditional Urfa cheeses (a white-brined Turkish cheese) produced from bovine milk, Food Control 19 (2008) 278-285.

[5] Blakesley R.W., Boezi J.A., A new staining technique for proteins in polyacrylamide gels using Coomassie Brilliant Blue G250, Anal. Biochem. 82 (1977) 580-581.

[6] Bradley R.L., Arnold E., Barbano D.M., Semerad R.G., Smith D.E., Vines B.K., Chemical and physical methods, in: Marshall R.T. (Ed.), Standard Methods for the Examination of Dairy Products, 16th edn., American Public Health Association, Washington, USA, 1993, pp. 433-531.
[7] Gomez M.J., Rodriguez E., Gaya P., Nunez M., Medina M., Characteristics of Manchego cheese manufactured from raw and pasteurized ovine milk and with definedstrain or commercial mixed-strain starter cultures, J. Dairy Sci. 82 (1999) 2300-2307.

[8] Hayaloglu A.A., Brechany E.Y., Influence of milk pasteurization and scalding temperature on the volatile compounds of Malatya, a farmhouse Halloumi-type cheese, Lait 87 (2007) 39-57.

[9] Hayaloglu A.A., Guven M., Fox P.F., McSweeney P.L.H., Influence of starters on chemical, biochemical, and sensory changes in Turkish white-brined cheese during ripening, J. Dairy Sci. 88 (2005) 3460-3474.

[10] Hayaloglu A.A., Ozer B.H., Fox P.F., Cheeses of Turkey: 2. Varieties ripened under brine, Dairy Sci. Technol. 88 (2008) 225-244.

[11] IDF, Cheese and processed cheese-determination of the total solid content, IDF Standard 4A, International Dairy Federation, Brussels, Belgium, 1982.

[12] IDF, Milk, Determination of the nitrogen (Kjeldahl method) and calculation of the crude protein content, IDF Standard 20B, International Dairy Federation, Brussels, Belgium, 1993.

[13] Kahyaoglu T., Kaya S., Effect of heat treatment and fat reduction on the rheological and functional properties of Gaziantep cheese, Int. Dairy J. 13 (2003) 867-875.

[14] Kandarikis I.G., Moatsou G.A., Georgala A.I.K., Kaminarides S., Anifantakis E., Effect of draining temperature on the biochemical characteristics of Feta cheese, Food Chem. 72 (2001) 369-378.

[15] Kuchroo C.N., Fox P.F., Soluble nitrogen in Cheddar cheese: comparison of extraction procedures, Milchwissenschaft 37 (1982) 331-335.

[16] Lane C.N., Fox P.F., Role of starter enzymes during ripening of Cheddar cheese made from pasteurised milk under controlled microbiological conditions, Int. Dairy J. 7 (1997) 55-63.

[17] Lau K.Y., Barbano D.M., Rasmussen R.R., Influence of pasteurization of milk on protein breakdown in Cheddar cheese during aging, J. Dairy Sci. 74 (1991) 727-740.

[18] Law J., Fitzgerald G.F., Daly C., Fox P.F., Farkye N.Y., Proteolysis and flavour development in Cheddar cheese made with the 
single strains Lactococcus lactis ssp. lactis UC317 or Lactococcus lactis ssp. cremoris HP, J. Dairy Sci. 75 (1992) 1173-1185.

[19] Lynch C.M., McSweeney P.L.H., Fox P.F., Cogan T.M., Drinan F.D., Contribution of starter lactococci and non-starter lactobacilli to proteolysis in Cheddar cheese with a controlled microflora, Lait 77 (1997) 441-459.

[20] McSweeney P.L.H., Fox P.F., Lucey J.A., Jordan K.N., Cogan T.M., Contribution of the indigenous microflora to the maturation of Cheddar cheese, Int. Dairy J. 3 (1993) 613-634.

[21] McSweeney P.L.H., Hayaloglu A.A., O'Mahony J.A., Bansal N., Perspectives on cheese ripening, Aust. J. Dairy Technol. 61 (2006) 69-77.

[22] Michaelidou A., Alichanidis E., Urlaub H., Polychroniadou A., Zerfiridis G.K., Isolation and identification of some major watersoluble peptides in Feta cheese, J. Dairy Sci. 81 (1998) 3109-3116.

[23] Moatsou G.A., Kandarikis I.G., Georgala A.K., Alichanidis E.S., Anifantakis E.M., Effect of starters on proteolysis of Graviera Kritis cheese, Lait 79 (1999) 303-315.
[24] Ozer B.H., Robinson R.K., Grandison A.S., Textural and microstructural properties of Urfa cheese (a white-brined Turkish cheese), Int. J. Dairy Technol. 56 (2003) 171-176.

[25] Schlesser J.E., Schmidt S.J., Speckman R., Characterization of chemical and physical changes in Camembert cheese during ripening, J. Dairy Sci. 75 (1992) 1753-1760.

[26] Shakeel-Ur-Rehman, Banks J.M., McSweeney P.L.H., Fox P.F., Effect of ripening temperature on the growth and significance of non-starter lactic acid bacteria in Cheddar cheese made from raw or pasteurised milk, Int. Dairy J. 10 (2000) 45-53.

[27] Shalabi S.I., Fox P.F., Electrophoretic analysis of cheese, comparison of methods, Ir. J. Food Sci. Technol. 11 (1987) 135-151.

[28] Sheehan J.J., Oliveira J.C., Kelly A.L., McSweeney P.L.H., Effect of cook temperature on primary proteolysis and predicted residual chymosin activity of a semi-hard cheese manufactured using thermophilic cultures, Int. Dairy J. 17 (2007) 826-834.

[29] Urbach G., The flavour of milk and dairy products. II. Cheese: contribution of volatile compounds, Int. J. Dairy Technol. 50 (1997) 79-89. 